\title{
Technological Innovation as a Strategy for Competitive Advantage within the Namibian Banking Industry
}

\author{
${ }^{1}$ Asa Romeo Asa, ${ }^{2}$ Dennis Tsanga, ${ }^{3}$ Christeline Januarie, ${ }^{4}$ Mekelaye Kamati \\ Department of Management \\ Faculty of Management Sciences \\ Namibia University of Science and Technology
}

\begin{abstract}
The purpose of this paper is to analyse the effectiveness of technological innovation as a strategy for driving competitive advantage and increasing market share in the Namibian banking sector. A comprehensive literature review was done with the collaboration of a quantitative research approach to draw data relating to technological innovations and their impact on competitive advantage. Employees at Nedbank and FNB in Windhoek were selected as respondents representing the entire Namibian banking sector population. The findings revealed a positive correlation between technological innovations as a strategy and competitive advantage and increased market share. The current fourth industrial revolution (4IR) expects organizations, banks, particularly, to tailor their strategies to technological advancements the revolutions bring with the risk of losing market share to existing competitors and emerging challenger banks.
\end{abstract}

Keywords: Strategy; Strategic management; Competitive advantage; Technological innovation.

\section{Introduction}

History has noted that great wars won by countries resulted from military strategies that endured through the battles, and such is the same with the businesses in a VUCA 21st century. Without a strategy, businesses will not survive this volatile, uncertain, complex, and ambiguous (VUCA) thanks to the emergence of the 4IR. One of the key areas of sustainable competitive advantage in this era is technological innovations. The financial sector has experienced a lot of disruptions lately as technological advances forcefully shifted the rules of the game. There has been a lot of new players in the banking sector to challenge traditional banks, and technological innovations have made this possible. Still, an effective and healthy banking sector is essential for development and sustainable financial assistance to Small and Medium Enterprises (SMEs) (Ikechy and Anthony, 2021). The current era is characterized by insurance companies contemplating on offering banking services, with large chain supermarkets and telecommunication giants joining the band. Four major banks dominate the Namibian banking industry: Nedbank, Standard Bank, FNB, and Bank Windhoek. The threat of challenger banks for the dominant four in Namibia is imminent, with such calling for sustainable strategies to be in place to ensure a competitive edge and market dominance. The Namibian banks are expected to seek the precise approach/strategy that will drive and manage technological innovations to ensure an increased share of the market and sustainable competitive advantage. When businesses continuously develop, apply, and achieve new ideas, value is added to the organization, survival, sustenance (Obrenovic et al. 2020), and ultimately competitive advantage (Horta, Silvera \& Camacho, 2015). In recent years, many academics and companies have been researching how the banking sector is being significantly disrupted by technological advancements resulting in increased publications of this topic.

Nevertheless, this paper aims to add to this body of knowledge by looking at technological innovations as a strategic driver of competitive advantage in the banking sector. This paper is organized in the following manner: Preceding this introduction about technological innovation as a strategy for competitive advantage, section 2 embroiders the literature review on the subject matter, outlining the concept of strategy and strategic management, technological innovation, and digital technology in the banking sector with the importance of technological innovation strategy concluding the section. Research methodology is explained in section 3, while section 4 provides an overview of the results and findings. Lastly, section 5 concludes the paper. 


\section{Literature Review}

\subsection{Concept of Strategy and Strategic Management}

A strategy is an integrated and coordinated set of commitments and actions designed to exploit core competencies and gain a competitive advantage (Hitt et al., 2017). All attempts by an organization to succeed emanating from idea generation, decision-making, and day-to-day activities constitute a strategy. The chosen strategy significantly conditions market success and failure (Obrenovic and Obrenovic, 2012). Thompson et al. (2016) state that a company's strategy is the set of actions that its managers take to outperform its competitors and achieve superior profitability. This success sought for is lasting and not temporary with the organization's future, and growth is secured. Strategic management consists of the analyses, decisions, and actions an organization undertakes in order to create and sustain competitive advantages (Dess et al., 2014). Firms need to acknowledge that there is no permanent competitive advantage. Hence the need for continual innovative tendencies aligns organization strategy with the current business environment. Competitive advantage is defined as implementing a strategy that creates superior value for customers that is difficult for competitors to duplicate or too costly to imitate (Hitt et al., 2017). Hence, Namibian banks are expected to continuously formulate and implement value-creating strategies to attain sustainable strategic competitiveness.

\subsection{Technological Innovation}

Innovation is a key organizational process, and companies have to continuously increase the offer of innovative products and services (Fratričová et al., 2020). The current volatile business environment requires firms to consistently generate ideas that enable them to tailor-make their products and or services in line with the current needs and wants of the market for them to remain relevant and ahead of the competition. Innovation is defined by Vaughan (2014) as the process of invention, development, and implementation of new ideas, products, services, technologies, systems, and programs. Radical and incremental innovation are conducive to the financial performance of organizations (Abiodun, 2017). As businesses embrace technology and institute it in their processes, products, and services, value is created, thus imparting a positive influence on firms' success. Hence, innovation has a great influence on how opportunities are derived. However, it is noted with concern that traditional banks have been suffering from technological inertia, with most of them tending to take a relaxed approach when it comes to technology issues, leading them to lowly embrace new ways of doing things. As a result of their inflexibility in technological advancements, small businesses in the form of challenger banks with their thirst to survive and grow that benefit in the process by pioneering new technological ways of doing things shunned by large banks.

\subsection{Strategy Formation and Implementation}

At the center of every business' success is the ability to create/develop, implement/execute, and successfully achieve set objectives and goals through the application of different strategies. Formulating a strategy is not easy, but implementing it is even more difficult as a well-formulated strategy on its own is not of value unless it has been successfully implemented and executed. Herbiniak (2006) argued that while strategy formulation is difficult, making strategy work and executing it is even more difficult. In support of this, Cater and Pucko (2010) concluded that while $80 \%$ of firms have the right strategies, only $14 \%$ have managed to implement them well. Strategy execution is commonly the most complicated and time-consuming part of strategic management, while strategy formulation is primarily an intellectual and creative act involving analysis and synthesis (Bell et al., 2010). Strategy implementation is the stage in the strategic management process where actual action needs to be taken to implement the formulated strategies and can be a very daunting task, especially in the imminent virtual banking industry, which is characterized by rapid changes.

\subsection{Digital Technology in the Banking Sector}

Financial services used to change slowly, with banking changing even more slowly, as evidenced by most banks' continuous distribution of a large portion of their products through branch networks more than 25 years after the internet launch (Cranston, 2019). In South Africa, as much as in other countries, this era has ended as new banks with leaner, cheaper business models and highly virtual enter the market. This is the new trend in the banking sector globally as technology advances. The banking sector is highly competitive in Namibia, whose population is not more than three million. The emergence of the internet has transformed the ways banking services are delivered in the 21 st century, thus making it crucial for the banks to incorporate such in their bid to enhance customer satisfaction. According to Kamutuezu (2016), from the Namibian perspective, there has been increased use of digital technology in transacting online at any given time as banks introduced digital platforms such as e-wallet, blue-wallet, easy-wallet, and internet banking. These technologies are still facing some resistance with some clients due to cyber-criminal activities, lack of knowledge of the benefits the systems come with, and sheer ignorance of the availability of such facilities, hence the reliance on conventional banking ways. In support of this notion, Behzod and Richard (2017) highlighted that some customers still depended on physical evidence rather than digital technology in an era of self-service through technology. 
However, from a futuristic point of view, the target market is shifting from the elderly to the millennials (Generation Y known as digital natives) and new generations such as Generation $\mathrm{Z}$ (the centennial generation) who have the internet as part of their DNA, thus highly technological conscious. Failure by banks to move in this direction results in a loss of competitive urge against robust competitors, especially new innovative entrants. As more and more of the world population thrives on keeping abreast with the ever revolutionizing technology in the global economy, the onus lies with the banks to follow these trends in consumer behavior and align their activities accordingly to elevate their performance in turn profitability. The above analysis thus forces the banks to plan, formulate and implement strategies that will ensure competitiveness in this increasingly competitive market.

\subsection{Importance of Technological Innovation Strategy}

\section{Technological innovation strategy is important in so many ways, including the following:}

Improving efficiency and effectiveness - the banking sector is one of the highly technology-driven industries where technological competition on a local and global scale is a critical element that needs utmost attention from managers. In 1911 by Joseph A. Schumpeter, an Austrian political economist, alleged that technological progressions would be the main push or pull force behind drastic changes in the form of emergence, fusion, disruption, and evolution of industries over time with the rapid changes giving birth to what is now experienced as VUCA business environment (Mahmood et al., 2013). Therefore, to remain relevant and competitive, banks should adopt continuous strategies that aim to synchronize business activities with current technological trends. This calls for the utilization of technological innovations such as Artificial Intelligence (AI), Big Data, Internet of Services (IOS), and Chatbot Systems to ensure effective and efficient delivery of services to banking customers.

Improving competitiveness and profitability - organizations that pioneer new technologies and innovations always stay ahead of the pack as they continuously enjoy first-mover advantages and create value, benefiting customers. According to Liu et al. (2016), assessing an organization's technological capabilities determines its ability to develop and introduce new products that meet market needs, to manufacture these products using the appropriate technologies and processes, to develop new technologies and products to meet future needs, and to quickly respond to unexpected technology updates by competitors and to unforeseen opportunities. In so doing, organizations can create sustainable competitive advantage in so many ways as, among others, attracting and retaining highly competent and rare skilled human capital. Hence, innovation (Bekmez, 2013) is one of the key driving forces that generate a sustainable competitive advantage in markets.

Ease of service delivery - one of the key success factors within the banking industry is exceptional customer service, which aims to delight customers by offering those services way beyond their expectations. There is a positive rapport between customer service and ICT (Kabanda, 2014), with banks benefiting hugely from the adoption of ICT, which has seen a positive global response by customers. With ICT, banking has been made very easy and flexible as time, and geographical barriers to transacting have been eliminated. However, efforts should be made by banks and other businesses at large to develop ways of protecting their customers from cyber-crime, as online trading has also become the playground for fraudsters.

\section{Research Methodology}

In order to critically understand the extent of technological innovations in creating competitive advantage and increasing an organization's market share, a comprehensive literature review was done with the collaboration of a quantitative research approach. The literature review was carried out through the use of major scientific literature databases from SABINET and Google Scholar. Additionally, peer-reviewed journal articles, books, and other documentation such as electronic business newspapers were used as secondary data sources. Theories of technological innovation were investigated, and in-depth literature relating to strategy and strategic implementation was identified and analyzed, linking them to the current technological trends within the business environment, specifically the banking sector.

In order to acquire objective information, a quantitative study was done in Windhoek with data collected from two of the dominating banks: Nedbank and FNB branches. Questionnaires were used as the main tool od data collection were respondents representing the target population made up of all licensed commercial banking institutions in Namibia, i.e., Bank Windhoek Limited, First National Bank Namibia Limited, Nedbank Namibia Limited, Standard Bank Namibia Limited, Trustco Bank Namibia Limited, Banco Atlántico (branch of foreign banking institution), Bank BIC Namibia Limited and Letshego Bank Namibia Limited. In addition, a purposive/ judgemental sampling technique was used to 
select the sample of 80 respondents, with 40 respondents from employees at Nedbank and the other 40 respondents from FNB employees as they are well acquainted with the issues pertaining to technological innovations at their workplaces.

The data gathered was then inputted into Excel Spreadsheet software for classification and tabulation to ease analysis and interpretation as totals from all categories were converted into percentages. It is in line with Leady and Ormrod (2010) citings that an electronic spreadsheet is a software program that allows a researcher to manipulate data displayed in tables, graphs, pie charts, histograms, and so forth.

\section{Results and Discussion}

Results from the quantitative study revealed that $60 \%$ of the respondents fell between the ages of $21-35$ years, making up the majority, with $33 \%$ of the respondents falling in the category of $36-50$ years and the remaining $7 \%$ the elderly above 50 years of age. With regard to years of service within the banking sector, the following results were acquired: respondents who served the banks for 1-5 years constituted $40 \%$, making up the majority with those who served for 1115 years coming second at $20 \%$ while $7 \%$ was made up of those that had served between 6-10 years.

The above demographics reveal that most of the employees in the banking sector are young adults who are well placed to understand the effectiveness and importance of technology in the current business world. When asked about their position regarding technological innovation improving profitability and competitiveness, $87 \%$ (as shown in the figure below with $47 \%$ agree and $40 \%$ strongly agree) consented to the notion, which aligns with remarks by Dognson et al. (2008) that firms that get technological innovation strategy right, create value and profit, develop sustainable competitiveness, and become vibrant, fun places to work, attracting and retaining the most productive and creative staff.

Figure 1: Improving profitability and competitiveness

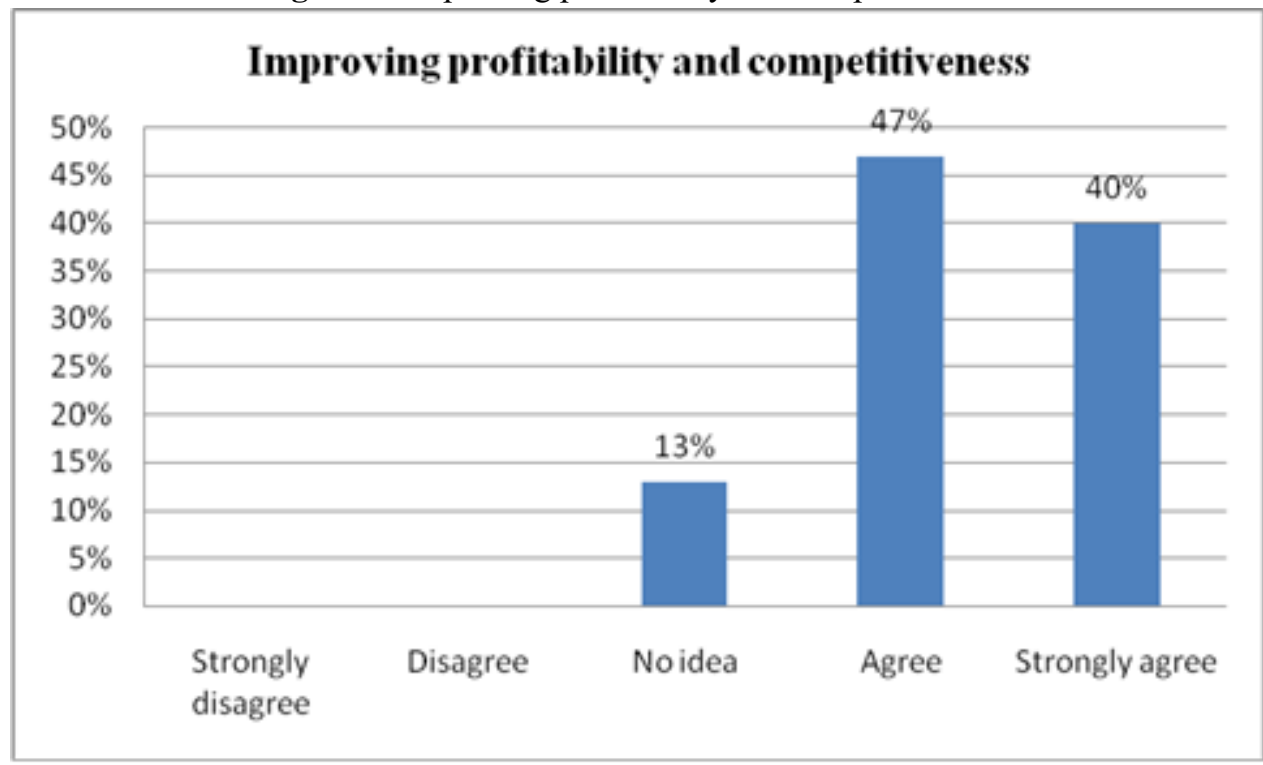

With reference to whether technological innovations improve efficiency and effectiveness, $80 \%$ (40\% agree and $40 \%$ strongly agree) agreed, while a paltry $7 \%$ professing no knowledge as shown in Figure 2 below:

Figure 2: Improving efficiency and effectiveness 


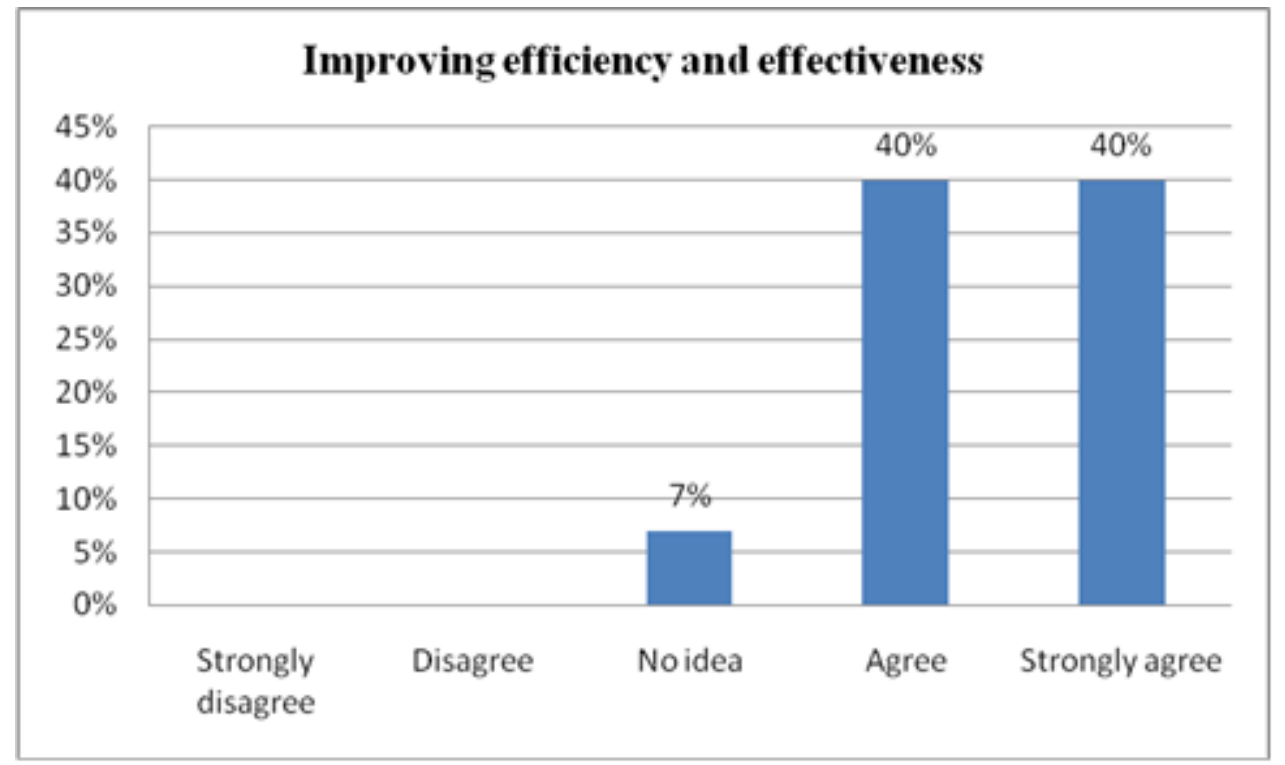

These observations tally with the literature stated by Ngina (2016) that effectiveness and efficiency are the core of service provision if any service provider is to survive in a competitive industry.

When asked about the effects of technological innovation as a competitive advantage strategy on whether it leads to sustainable competitive advantage, the results as shown in Figure 3 below show that the majority of the respondents agree ( $87 \%$ with $27 \%$ strongly agreeing and $60 \%$ agreeing) that it does lead to such an advantage.

Figure 3: Lead to competitive advantage

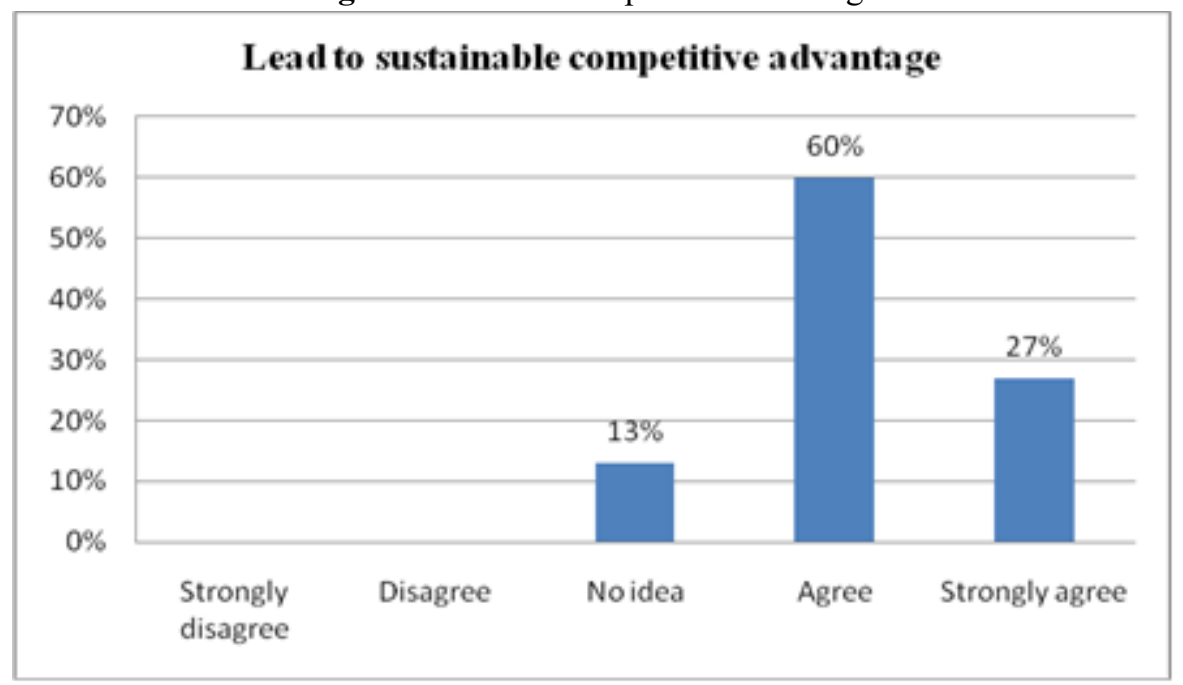

It corresponds to literature by Hana (2013) that technological innovation fosters competitive advantage. Additionally, Casarez and Mulholland (2009) support this view by reiterating that absence of technological innovations is synonymous with businesses that fail to adjust to technological advancements and thus susceptible to lack of competitiveness and complacency as there will not be responding to the changes in the global environment they are expected to.

\section{Conclusion}

In conclusion, generally, the literature and findings from the quantitative study at two of the major banks in Namibia reveal that the pursuit of technological innovations will increase the competitiveness of banks and, eventually, their market share. The current business environment is very volatile, with many disruptive changes, mainly in technology, creating gaps in the market for opportunities for new challenger/innovative banks to step in. Traditional banks are subsequently expected to be craft competent and develop and implement strategies that align with the changing global trends, needs, and wants of consumers or face loss of market share.

\section{References}

- Abiodun, T.S. (2017). An Examination of the Relationships Between Different Types of Innovation and Firm Performance and the Mediating Effect of Radical and Incremental Innovations on These Relationships. International Journal of Innovation and Economic Development, 3(5), 38-58. 
- Bekmezc, M. (2013). Taking competitive advantage by business model innovation. Journal of Management and Economics, 20(1), 291-314.

- Casarez, V., \& Mulholland, A. (2009). Adopting to ever-changing technology with a complete enterprise 2.0 solution. California: ORACLE.

- Cater, T., \& Pucko, D. (2010). Factors of effective strategy implementation: Empirical evidence from Slovenian business practice. Journal for East European Management Studies, 15(3), pp. 207-236. Crossref

- Cranston, S. (2019). Digital banks: Can SA's new challenger banks knock out the 'big four'? BL Premium, financial mail, March 28. Retrieved June 30, 2020, from: https://www.businesslive.co.za/fm/features/coverstory/2019-03-28-can-sas-new-challenger-banks-knock-out-the-big-four/

- Dess, G. G., Lumpkin, G. T., Eisner, A. B., \& McNamara, G. (2014). Strategic management: Text and cases. 7th ed. New York: McGraw-Hill Education

- Dodgson, M., Gann, D., \& Salter, A. (2008). The management of technological innovation: Strategy and practice. Oxford: Oxford University Press.

- Fratričová, A., Überwimmer, M. \& Füreder, R. (2020). Service Innovation Processes in SMEs in Upper Austria. Journal of International Business Research and Marketing, 5(3), 26-31.

- Hana, U. (2013). Competitive advantage achievement through innovation and knowledge. Journal of Competitiveness, 5(1), 82-96. Crossref

- Herbiniak, L.G. (2006). Obstacles to effective strategy implementation. Organizational Dynamics, 35(1), pp. 12-31. Crossref

- Hitt, A. H., Ireland, R. D. \& Hoskisson, R, E. (2017). Strategic management competitiveness and globalization. 8th ed. Ohio: South Western/Thomson Learning.

- Ikechi, K.S. \& Anthony, N. (2021). Commercial Bank Loans and the Performance of Small and Medium Scale Enterprises (SMEs) In Nigeria. International Journal of Innovation and Economic Development, 6(6), 46-59.

- Kabanda, G. (2014). The impact of ICTs on customer service excellence in Zimbabwe. International Journal of Advanced Manufacturing, 4(5), 312-324.

- Kamutuezu, E. J. (2016). The adoption of digital banking in Namibia. Master's Thesis. Noida: Amity University.

- $\quad$ Liu, L., \& Jiang, Z. (2016). Influence of technological innovation capabilities on product competitiveness. Industrial Management \& Data Systems, 116(5), 883-902. doi:10.1108/imds-05-2015-0189 Crossref

- Mahmood, Z., Amir, A., Javied, S., \& Zafar, F. (2013). Management and business research administration and management. Strategic Management of Technology and Innovation, 13(12). Retrieved March 12, 2019, from www.globaljournals.org

- Obrenovic, B., \& Obrenovic, S. (2012). Game Analysis of Google's Information Dissemination Strategy in China: a New Perspective for Knowledge Engineering. Systems Engineering Procedia, 3, 333-339.

- $\quad$ Obrenovic, B., Du, J., Godinic, D., Tsoy, D., Khan, M. A. S., \& Jakhongirov, I. (2020). Sustaining enterprise operations and productivity during the COVID-19 pandemic:"Enterprise Effectiveness and Sustainability Model". Sustainability, 12(15), 5981.

- Thompson, A. A., Peteraf, M. A., Gamble, J. E., \& Strickland, A. J. (2016). Crafting and executing strategy: the quest for competitive advantage : concepts and readings. 20th ed. New York: McGraw-Hill Education.

- Vaughan, J. (2013). Technological innovation: Perceptions and definitions. Library Technology Reports, 49(7). 